Health Programme Office, Centres for Disease Control, Atlanta, Georgia 30333 USA.

\section{References}

${ }^{1}$ Martin WJ, Morley DC, Woodland M. Interval between births in a Nigerian village. $\mathcal{F}$ Trop Pediatr 1964;10:82.

2 McBean AM, Foster SO, Herrmann KL, et al. Evaluation of a mass measles immunization campaign in Yaoundé, Cameroon. Trans $R$ Soc Trop Med Hyg 1976;70:206-12.

${ }^{3}$ Peetermans J. Vaccin Rougeoleux Vivant Attenue (Souche Schwarz) pour injection. Recherches et Industrie Therapeutiques, SA Welwyn Garden City: Smith, Kline and French, 1979. (Product data.)

${ }^{4}$ McAleer WJ, Markus HZ, McLeen AA, Buynak EB, Hilleman MR. The stability on storage at various temperatures of line measles, mumps and rubella virus vaccines in a new stabiliser. 7 Biol Stand 1980;8:281-7.

${ }^{5}$ Heymann DL, Nakano JH, Durand B, et al. Field trials of a heat-stable measles vaccine in Cameroon. $\mathrm{Br}$ Med $\mathcal{F}$ 1979;ii:99-100.

${ }^{6}$ Mathews HM. Persistence of malaria antibody in Tobago, West Indies, following eradication as measured by the indirect hemagglutination test. Am 7 Trop Med Hyg 1970;19:581.

${ }^{7}$ Hierholzer JC, Suggs MT. Standardization of viral hemagglutination and hemagglutination tests of erythrocyte suspensions. Applied Microbiology $1969 ; 18: 816$.

${ }^{8}$ Norrby E. Hemagglutination by measles virus. Proc Soc Exp Biol Med $1962 ; 11: 814$.

${ }^{9}$ World Health Organisation. Stability of freeze-dried measles vaccine. WHO Weekly Epidemiological Record $1981 ; 23: 177$.

(Accepted 18 fune 1982)

\title{
Are HLA antigens important in the development of alcohol-induced liver disease?
}

\author{
R FAIZALLAH, J C WOODROW, N K KRASNER, R J WALKER, A I MORRIS
}

\begin{abstract}
The prevalences of $10 \mathrm{HLA}-\mathrm{A}$ and $16 \mathrm{HLA}-\mathrm{B}$ antigens were determined in 50 patients with alcoholic cirrhosis and 120 alcoholic patients without cirrhosis and compared with those in a control group of 550 healthy subjects from the same geographical area. B40 was absent in the patients with cirrhosis but was found in $18(15 \%)$ of the patients without cirrhosis $(p=0.0087)$. No other association was noted.

It is concluded that there is no good evidence to date of an association between HLA antigen state and susceptibility to alcohol-induced cirrhosis.
\end{abstract}

\section{Introduction}

While the quantity of alcohol consumed and duration of consumption probably play a major part in the pathogenesis of alcohol-induced cirrhosis, other as yet poorly identified factors exist since most alcoholics do not develop cirrhosis despite very heavy drinking. ${ }^{1}$ One possible factor-genetic predispositionhas been studied in some detail by investigation of the HLA polymorphism among alcoholics. The results have so far been conflicting, some workers showing no evidence of any association between a particular HLA antigen and alcohol-induced cirrhosis ${ }^{2}$ while others have shown possible linkage with A28, B8, B13, and $B 40,{ }^{3-5}$ all in fairly small groups. In the present study we investigated a larger number of patients to assess their antigen state and determine whether there was any association with alcohol-induced cirrhosis.

Gastrointestinal Unit, Walton Hospital, Liverpool L9 1AE

R FAIZALLAH, MB, MRCP, medical registrar

N K KRASNER, MD, FRCP, consultant physician and gastroenterologist

R J WALKER, BSC, FRCP, consultant physician

A I MORRIS, MD, MRCP, consultant physician and senior lecturer

Department of Medicine, University of Liverpool, Liverpool L69 3BX J C WOODROW, MD, FRCP, professor

\section{Subjects and method}

Over two years we studied 170 consecutive alcoholics, all of whom had been admitted for detoxification or treatment of alcoholism. Fifty patients showed signs of chronic liver disease, and histology of liver biopsy specimens in 39 showed cirrhosis; in the remaining 11 liver biopsy was contraindicated and cirrhosis was diagnosed on clinical and biochemical grounds-for example, evidence of portal hypertension or hepatic encephalopathy. The group with cirrhosis comprised 15 women (mean age 58.1 \pm SD 10.5 years) and 35 men (mean age 54.9 \pm 9.4 years). The mean alcohol intake in this group was $194+96 \mathrm{~g} /$ day for a mean duration of $15 \cdot 3+8 \cdot 3$ years. Of the remaining 120 patients, 26 had no biochemical evidence of liver injury or any clinical evidence of liver disease; liver biopsy was unjustified in these and they were included in the group without cirrhosis. In the remaining 94 there was biochemical evidence of liver injury and liver biopsy yielded either normal findings or evidence of liver injury short of cirrhosis, the commonest being steatosis. Of these patients, 51 were women (mean age 48.1 $\pm 12 \cdot 8$ years) and 69 men (mean age $48.4 \pm 12.9$ years.) The mean alcohol intake in this group without cirrhosis was $186 \cdot 8 \pm 115 \mathrm{~g}$ pure alcohol daily for a mean of $8 \cdot 5 \pm 7 \cdot 4$ years. Lymphocytes from venous blood samples were typed by a modified cytotoxicity technique ${ }^{6}$ for specificity to 10 HLA-A and 16 HLA-B antigens. $\mathrm{ABO}$ blood groups were determined on the blood samples and compared with those of a large control series from the same geographical area.

Serum samples were tested for the presence of antinuclear, smoothmuscle, mitochondrial, parietal cell, and reticulin antibody by fluorescence antibody methods. Tests for the presence of hepatitis B surface antigen ( $\mathrm{HBsAg})$ and hepatitis $\mathrm{B}$ core antigen $(\mathrm{HBcAg})$ were carried out in most cases. Relative risks were calculated according to the method of Haldane. ${ }^{?}$

\section{Results}

Table I gives the prevalences of the HLA-A and B series antigens in alcoholic patients with and without cirrhosis and the controls together with the significances of the differences between the three groups. B40 was absent in the patients with cirrhosis but present in $18(15 \%)$ of those without cirrhosis and in $64(11.6 \%)$ of the normal controls. No other noticeable differences were apparent, in particular with regard to $\mathrm{A} 28, \mathrm{~B} 8$, and $\mathrm{B} 13$.

Table II gives the prevalences of the $\mathrm{ABO}$ blood groups in patients and controls; there was no significant difference between the three groups. Four patients showed very low titres of antinuclear antibodies; two had antibodies to smooth-muscle, one to reticulin, and six to 
parietal cell antibodies; and none had antimitochondrial antibodies. $\mathrm{HBsAg}$ was absent in all the patients tested, and only four were positive for $\mathrm{HBcAg}$, which is a lower prevalence than has been cited in recent reports. ${ }^{8}{ }^{\circ}$

\section{Discussion}

In an earlier study A28 was noted to be absent in all the patients with cirrhosis in the series. ${ }^{3}$ Although in our series the prevalence of A28 was lower in the group with cirrhosis, the difference was not significant (table I). In the same series B8

TABLE I-Prevalences of $26 \mathrm{HLA}$ antigens in patients and controls (figures are numbers ( $\%)$ of subjects positive for each antigen)

\begin{tabular}{|c|c|c|c|}
\hline \multirow{2}{*}{ Antigen } & \multicolumn{2}{|c|}{ Alcoholic patients } & \multirow{2}{*}{$\begin{array}{l}\text { Controls } \\
(n=550)\end{array}$} \\
\hline & $\begin{array}{l}\text { With cirrhosis } \\
\quad(n=50)\end{array}$ & $\begin{array}{l}\text { Without cirrhosis } \\
\qquad(\mathrm{n}=120)\end{array}$ & \\
\hline $\begin{array}{l}\text { A1 } \\
\text { A2 } \\
\text { A3 } \\
\text { A9 } \\
\text { A10 } \\
\text { A11 } \\
\text { A28 }\end{array}$ & $\begin{array}{l}16(32) \\
22(44) \\
14(28) \\
10(20) \\
5(10) \\
6(12) \\
1(2)\end{array}$ & $\begin{array}{l}48(40 \cdot 0) \\
62(51.7) \\
33(27.5) \\
19(15 \cdot 8) \\
12(10.0) \\
17(14 \cdot 2) \\
11(9.2) \mathrm{p}=0.18\end{array}$ & $\begin{array}{l}193(35 \cdot 1) \\
245(44 \cdot 6) \\
154(28 \cdot 0) \\
101(18 \cdot 4) \\
51(9 \cdot 3) \\
74(13.5) \\
32(5 \cdot 9) \mathrm{p}=0.4\end{array}$ \\
\hline $\begin{array}{l}\text { A29 } \\
\text { AW30/31 } \\
\text { AW 32 } \\
\text { B5 } \\
\text { B7 } \\
\text { B8 }\end{array}$ & $\begin{aligned} & 5(10) \\
& 1(2) \\
& 4(8) \\
& 5(10) \\
& 20(40) \\
& 15(30)\end{aligned}$ & $\begin{aligned} 4(3 \cdot 3) \\
4(3 \cdot 3) \\
5(4 \cdot 5) \\
7(5.8) \\
38(31 \cdot 7) \\
28(23.3) p=0.47\end{aligned}$ & $\begin{array}{l}40(7 \cdot 2) \\
28(5 \cdot 0) \\
36(6 \cdot 6) \\
49(8.9) \\
161(29 \cdot 3) \\
156(28.4) p=0.93\end{array}$ \\
\hline $\begin{array}{l}\mathrm{B} 12 \\
\mathrm{~B} 13\end{array}$ & $\begin{aligned} 17(34) \\
2(4)\end{aligned}$ & $\begin{array}{l}32(26.7) \\
2(1.7) \mathrm{p}=0.72\end{array}$ & $\begin{array}{r}166(30.2) \\
26(4.7) p=1.00\end{array}$ \\
\hline $\begin{array}{l}\text { B14 } \\
\text { B15 } \\
\text { BW16 } \\
\text { B17 } \\
\text { B18 } \\
\text { BW21 } \\
\text { BW22 } \\
\text { B27 } \\
\text { BW35 } \\
\text { B37 } \\
\text { B40 }\end{array}$ & $\begin{array}{l}4(8) \\
7(14) \\
3(6) \\
3(6) \\
4(8) \\
1(2) \\
5(10) \\
2(4) \\
9(18) \\
3(6) \\
0\end{array}$ & $\begin{array}{l}14(11 \cdot 7) \\
12(10 \cdot 0) \\
3(2 \cdot 5) \\
13(10 \cdot 8) \\
8(6 \cdot 8) \\
2(1 \cdot 7) \\
4(3 \cdot 3) \\
18(15 \cdot 0) \\
19(15 \cdot 8) \\
4(3 \cdot 3) \\
18(15 \cdot 0) \mathrm{p}=0.0087\end{array}$ & $\begin{array}{l}40(7 \cdot 3) \\
64(11 \cdot 6) \\
25(4 \cdot 6) \\
48(8 \cdot 7) \\
30(5 \cdot 5) \\
26(4 \cdot 8) \\
30(5 \cdot 5) \\
50(9 \cdot 1) \\
65(11 \cdot 8) \\
16(2 \cdot 9) \\
64(11 \cdot 6) \mathrm{p}=0.02\end{array}$ \\
\hline
\end{tabular}

was claimed to be increased in the group with cirrhosis; this too was not supported in our study, the relative risk being $1 \cdot 1$ $(p=0.93)$. Likewise, other studies have failed to show this association-if the results from the present study and those from seven other centres are combined ${ }^{2-510-12}$ the relative risk of developing cirrhosis in people with B8 is $1.28(p=0.78)$, with evidence of heterogeneity between the various centres. No significant difference could be found when men and women with cirrhosis were analysed separately in our series: five women $(33 \%)$ and 10 men $(28.6 \%)$ had B8 antigen.

A more recent series from Chile showed a significantly higher prevalence of $\mathrm{B} 13$ in patients with cirrhosis ${ }^{4}$; this again was not supported by our series $(p=1$; table $I)$. In a small series from Oslo B40 was more common among patients with cirrhosis, ${ }^{5}$ yet we found it to be absent in all 50 patients $(p=0.0082)$; this is probably not statistically significant since a probability value of less than 0.0019 would have to be observed before any difference is considered to be significant when 26 specificities are being compared. ${ }^{13}$ When results from five previous series

TABLE II-Prevalence of $A B O$ blood groups in patients and controls (figures are numbers (\%) of subjects)

\begin{tabular}{cccc}
\hline \multirow{3}{*}{$\begin{array}{c}\text { Blood } \\
\text { group }\end{array}$} & \multicolumn{2}{c}{ Alcoholic patients } & \multicolumn{1}{c}{$\begin{array}{c}\text { Control11 } \\
(\mathrm{n}=15377)\end{array}$} \\
\cline { 2 - 3 } & $\begin{array}{c}\text { With cirrhosis } \\
(\mathrm{n}=50)\end{array}$ & $\begin{array}{c}\text { Without cirrhosis } \\
(\mathrm{n}=120)\end{array}$ & \\
\hline $\mathrm{A}$ & $18(36)$ & $36(29 \cdot 9)$ & $6012(39 \cdot 1)$ \\
$\mathrm{B}$ & $5(10)$ & $16(13 \cdot 4)$ & $1445(9 \cdot 4)$ \\
$\mathrm{AB}$ & $1(2)$ & $5(3 \cdot 9)$ & $384(2 \cdot 5)$ \\
$\mathrm{O}$ & $26(52)$ & $63(52 \cdot 8)$ & $7519(48 \cdot 9)$ \\
\hline
\end{tabular}

are combined with ours with regard to $B 40^{2451011}$ the combined relative risk of developing cirrhosis is $1.8(\mathrm{p}=0.017)$, with evidence of appreciable heterogeneity between the various centres $(p=0.018)$

This heterogeneity and lack of consistency in the results from various centres can only reinforce our conclusion that there is no true association between a particular HLA antigen and alcohol-induced cirrhosis. This in turn would suggest that other perhaps more important factors might be responsible for the development of alcoholic cirrhosis. Possibilities include autoimmune reactions that occur in alcoholism ${ }^{14-18}$ and the metabolic derangements in the liver induced by alcohol. ${ }^{19-21}$ More recently racial variation in aldehyde dehydrogenase isoenzymes has been shown between Japanese and Europeans. ${ }^{22}{ }^{23}$ It may be argued that these factors may be genetically controlled. If such control does exist there is no consistent evidence that it is in the HLA chromosome region.

\section{References}

1 Insunza I, Iturriaga H, Ugarte G, Aitschiller H. Estudio clinico pathologico del dano nepatico en pacientes alcoholicos. Rev Med Chil 1969;97: 765-72.

${ }^{2}$ Scott BB, Rajah SM, Losowsky MS. Histocompatibility antigens in chronic liver disease. Gastroenterology 1977;72:122-5.

${ }^{3}$ Bailey RJ, Krasner N, Eddleston ALWF, et al. Histocompatibility antigens, autoantibodies, and immunoglobulins in alcoholic liver disease. Br Med F 1976;ii:727-9.

4 Melendez M, Vargas-Tank L, Fuentes C, et al. Distribution of HLA histocompatibility antigens, $\mathrm{ABO}$ blood groups and $\mathrm{Rh}$ antigens in alcoholic liver disease. Gut $1979 ; 20: 288-90$.

${ }^{5}$ Bell H, Nordhagen R. Association between HLA-BW40 and alcoholic liver disease with cirrhosis. $\mathrm{Br} \mathrm{Med}$ f 1978;i :822.

6 Terasaki PI, McClelland JD. Microdroplet assay of human serum cytotoxins. Nature $1964 ; 204: 998-1000$.

${ }^{7}$ Haldane JBS. The estimation and significance of the logarithm of a ratio of frequencies. Ann Hum Genet 1966;20:309-11.

${ }^{8}$ Mills PR, Pennington TH, Kay P, MacSween RNM, Watkinson G. Hepatitis Bs antibody in alcoholic cirrhosis. F Clin Pathol 1979;32: 778-82.

${ }^{9}$ Hilsop WS, Fullet EAC, Bouchier IAD, MacSween RNM. Serological markers of hepatitis $B$ in patients with alcoholic liver disease: a multicentre survey. $\mathcal{F}$ Clin Pathol 1981;34:1017-9.

10 Morris PJ, Vaughan H, Tait BD, Mackay IR. Histocompatibility antigen (HLA): associations with immunopathic diseases and with responses to microbial antigens. Aust NZ F Med 1977;7:616-24.

11 Kiernan TJ, Stevens FM, Bourke M, McCarthy CF. HLA types in liver disease in the west of Ireland. Ir F Med Sci 1980;149:63-5.

12 Seignalet J, Blanc F, Lapinski H. Groupes HLA des cirrhotiques alcoholiques. Nouv Presse Med 1980;9:712.

13 Svejgaard A, Jersild C, Nielsen LS, Bodmer WF. HLA antigens and disease: statistical and genetical consideration. Tissue Antigens 1974;4: 95-105.

14 Krasner $N$, Davis $M$, Portman $B$, Williams $R$. The changing pattern of alcoholic liver disease in Great Britain: relationship to sex and manifestations of autoimmunity. Br Med $\mathcal{F} 1977 ; \mathrm{i}: 1497$.

15 Berenyi MR, Straus B, Cruz D. In vitro and in vivo studies of cellular immunity in alcoholic cirrhosis. Am 7 Dig Dis 1974;19:199-205.

16 Bernstein IM, Webster KH, Williams RC Jr, Struckland RG. Reduction in circulating $\mathrm{T}$ lymphocytes in alcoholic liver disease. Lancet 1974 ;ii: 488.

17 Sorrell MF, Leevy CM. Lymphocyte transformation and alcoholic liver injury. Gastroenterology $1972 ; 63: 1020-5$.

18 Zetterman RK, Chen T, Leevy CM. Role of altered lymphocyte function in alcoholic liver disease. Gastroenterology 1974;67:837.

19 Rubin E, Hutterer F, Lieber CS. Ethanol increases hepatic smooth endoplasmic reticulum and drug-metabolizing enzymes. Science 1968; 159:1469.

${ }^{20}$ Rubin E, Leiben CS. Hepatic microsomal enzymes in man and rat: induction and inhibition by ethanol. Science 1968;162:690-1.

${ }^{21}$ Cavulli N, Manenti F, Gallo M, Salvioli GG. Alcohol-drugs interaction in man: alcohol and tolbutamide. Eur $\mathcal{F}$ Clin Invest 1971;1:421-4.

22 Agarwal DP, Harada S, Goedde HW. Racial differences in biological sensitivity to ethanol: the role of alcohol dehydrogenase and aldehyde dehydrogenase isoenzymes. Alcoholism: Clinical and Experimental Research $1981 ; 5: 12-6$.

${ }^{23}$ Harada S, Agarwal DP, Goedde HW. Aldehyde dehydrogenase deficiency as cause of facial flushing reaction to alcohol in Japanese. Lancet 1981; ii :982.

(Accepted 23 fuly 1982) 